\title{
Domestic sexual child abuse: Social and social-cultural aspects*
}

\author{
Zh.V. Puzanova, V.M. Filippov, M.A. Simonova, T.I. Larina \\ RUDN University \\ Miklukho-Maklaya St., 6, Moscow, 117198, Russia \\ (e-mail:simonova-ma@rudn.ru; filippov-vm@rudn.ru; \\ puzanova-zhv@rudn.ru; larina-ti@rudn.ru)
}

\begin{abstract}
The ratification of the Lanzarote Convention by Russia in 2013 entails several issues that cannot be resolved without the help of social-humanitarian sciences. Information from sociology, psychology, and jurisprudence has been used to create a concept for the empirical study of the domestic violence against children - to improve the implementation of the Convention in Russia. The concept considers two aspects of the problem - social and social-cultural. The article presents the Russian experience of how the provisions of the Council of Europe Convention on the Protection of Children against Sexual Exploitation and Sexual Abuse are implemented. The authors analyze statistical data on the number of families in which a sexually abused child is brought up; the number of abortions and childbirths by minors; the number of minors in educational colonies; the work of the children's helpline; the number of mediation services; the number of social service organizations for families and children; the number of professionals working with children in programs aimed at preventing and protecting children from sexual exploitation and abuse; the number of organizations providing psychological-pedagogical and medical-social assistance; the number of specialized multifunctional centers providing assistance to families and child victims of sexual abuse; the number of specialized 'green' rooms for investigating crimes related to minors; the number of specialists accompanying minors who have come into conflict with the law at all stages of the investigation and court proceedings; the number of professionals trained under the Child Sexual Violence Protection Program and now assisting families and child victims of violence. The article will be useful for readers who study the implementation of the Lanzarote Convention and the issues of child sexual abuse and domestic violence.
\end{abstract}

Key words: violence; children; sexual abuse; victimology; public opinion; Lanzarote Convention; monitoring

It is estimated that one in five children fall victim to sexual violence - a serious human rights violation the Council of Europe has decided to combat - the Convention on the Protection of Children against Sexual Exploitation and Sexual Abuse (Lanzarote Convention) is the most advanced and complete standard in this field [5]. One of the most important ways of putting the policy and regulatory documents for child protection into action is to implement the provisions of the Convention adopted in Lanzarote (Canary Islands, Spain) on October 25, 2007 [14].

* (C) Zh.V. Puzanova, V.M. Filippov, M.A. Simonova, T.I. Larina, 2021

The article was submitted on 27.01.2021. The article was accepted on 02.04.2021. 
Russia ratified the document with reservations (Federal Law of May 7, 2013): Russia supports most of the provisions, but it is important to implement them following the norms of current legislation and customary law, based on the principles of reasonableness and expediency. Besides, there are several problems that require addressing not only by jurisprudence, but by other social-humanitarian sciences (Fig. 1).

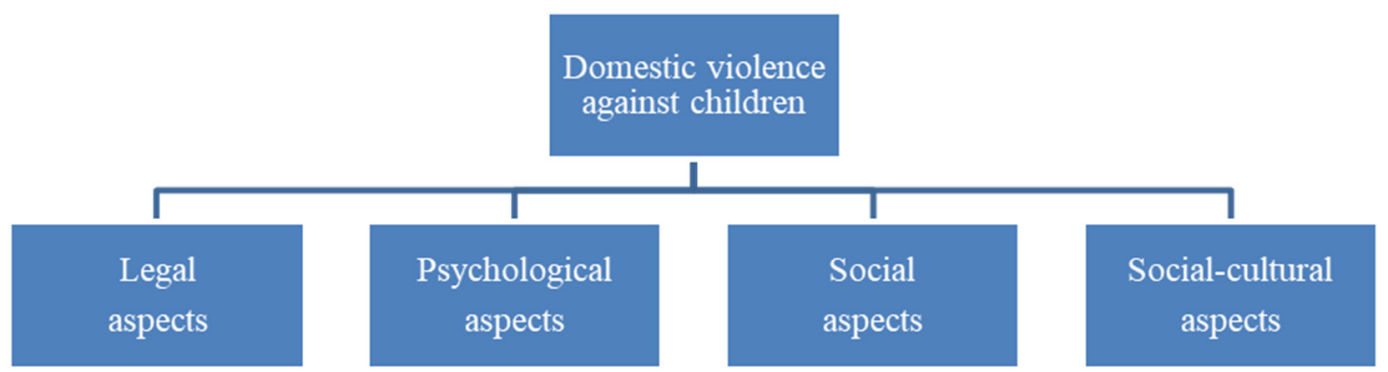

Figure 1. Social-humanitarian research of domestic violence against children

We suggest the following concept of empirical research of domestic violence against children (Fig. 2):

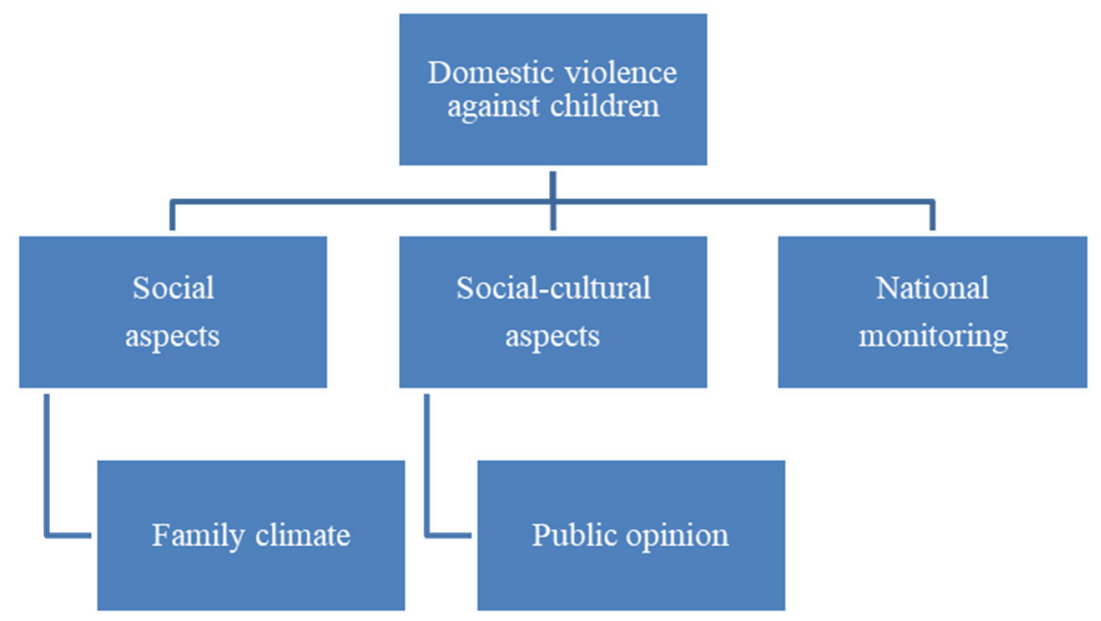

Figure 2. Empirical research of domestic violence against children

Social aspects. Domestic violence is defined as behavior carried out with the deliberate or unconscious intent of the aggressor to harm a family member. Factors that determine domestic violence are as follows: violence due to the stereotypes of family education adopted in a certain group; violence determined by such factors as social and economic situation, low income, unemployment, increase in the number of domestic conflicts leading to family situations in which parents harm their children due to the anger caused by the inability to fully perform their roles in the family [10]. 
Juvenile victimology examines such issues as the identity of the minor as a victim of criminal acts, the causes and conditions of victimization of minors and adolescents - to prevent and reduce crimes of this nature [9]. Victim traits can be divided into general - naivety, trustfulness, curiosity, physical weakness, submission and helplessness to the authority of the adult, impressiveness; and individual — psychological (violence, anxiety, aggressiveness, conflict, emotional instability), social (self-affirmation, the need to communicate, social relationships, family conditions).

One of the factors increasing the possibility of criminal offense against a child in the family is low income. Most often people committing a crime against minors have themselves been victims of parental abuse in the past and try to transfer the aggression on their own and others' children. Thus, victimization of the child leads to the criminalization of the adult. The situation of children living in dysfunctional families is particularly dangerous - alcoholism, drug addiction, unemployment, poor housing conditions, and large families. According to the studies conducted in Russia, cases of domestic violence account for $1 / 3$ of all cases of violence against minors [12].

Victimization factors include both internal (personal and behavioral features of victims) and external characteristics, in particular, pre-criminal situations (circumstances at the moment of the crime, unrelated to the victim's behavior). Internal victimization factors are closely related to the victim's personality, there are those types of victimization which in themselves determine the process of victimization (gender and age, victimhood and role pathology), as well as those types of victimization that are realized in the victim's behavior (victimization personality deformation, stressful victimhood) [16]. Related to victimology in this context is the term PTSD (post-traumatic stress disorder).

Child victims of sexual and physical abuse are more likely to experience frequent behavioral changes, underestimate themselves, are emotionally unstable and prone to immediate response, have difficulties in expressing positive emotions, and return to the psychologically traumatic situation through intrusive reproduction [3]. Children who witness domestic violence between their parents or other adults at home are not just passive observers. They are profoundly impacted by violence and coercive behavior at home, and they find complex, creative ways to manage and cope with these experiences. Children's experiences of domestic violence are like a double helix, with the twin strands of coping and damage closely interlinked. Children's capacity to be strong, to be agentic, to be resilient can only be read in the actions that function to undermine their development of agency and resilience, forms of relating that characterize violence, abuse, and coercive control [1].

All these aspects are subject to consideration within each specific culture, but the primary consideration of domestic violence should start with the cultures themselves, specifically the social-cultural characteristics of societies. Looking at the attitude towards people with disabilities in Russia, you can see that legislative acts cannot guarantee the progress of a particular issue without addressing public opinion and the study of social representations. The attitude to certain issues varies 
from one culture to another. For instance, in the RUDN study conducted in 2017, 416 people were interviewed representing the main faculties and institutes of the RUDN, taking into account the quotas - course and region of foreign students (Middle East, Europe, East Asia, CIS, Africa, Latin America). They were asked: "What is your attitude to the situation when a parent shouts at a child in a public place, on a scale from 0 to 5, where 0 - I find it difficult to answer, 1 - I consider it completely unacceptable, 5 - I consider it completely acceptable"? (Fig. 3). European students showed a calmer attitude to this phenomenon than students from Asia, even though such a social action is generally not approved. This example is not a vivid one, but even in this simple situation cultural differences can be seen.

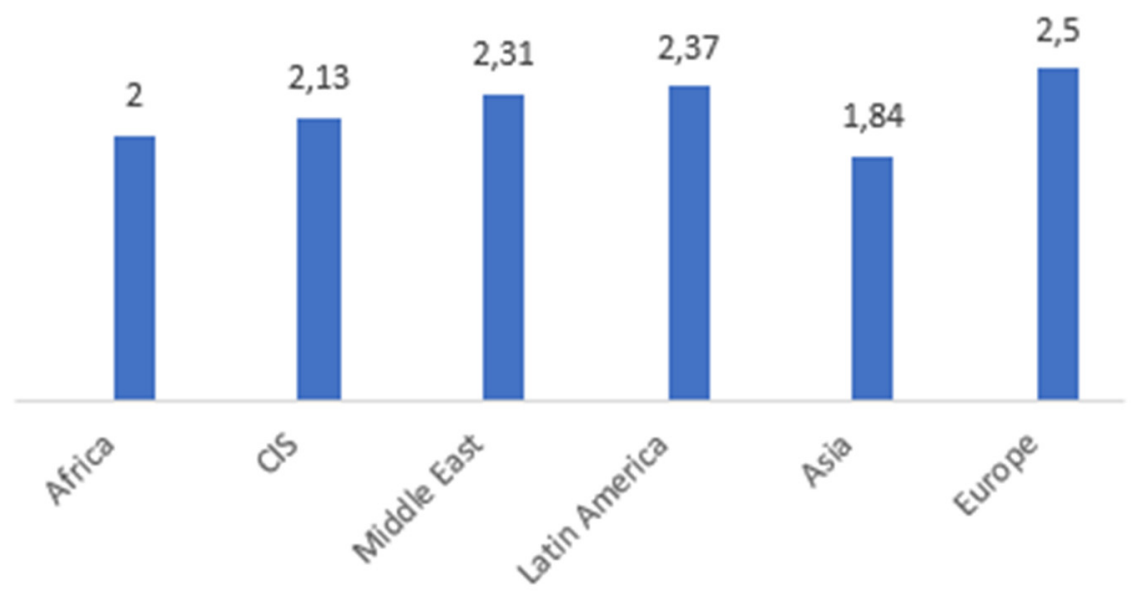

Figure 3. "What is your attitude to the situation when a parent shouts at a child in a public place?"

When talking about domestic violence, its study and application of legal measures for child protection, several social-cultural characteristics should be considered.

Mentality. Personal relationships are more important than laws for Russian people: we are ready to forgive our friends things that would never forgive other people [6]. There is also an informal rule 'do not rat on another', which has its roots in the Soviet times: "In Russia it is as follows: tricking a teacher is considered a valiant act, and passing all exams without attending any lectures is an achievement. But telling on someone means losing authority in the group. Since childhood, we are taught that it is bad behavior and it is not only about the university, but also about adult life" [2].

Opinion polls that work at the level of social perceptions can reveal such details. In the Russian culture, everything that happens in a family is not brought to public view and discussion. Stereotypes are firmly rooted in the Russian national mentality: proverbs such as 'foul one's own nest', 'lovers' tiffs are harmless' are common, there is also a Russian proverb 'if one hits you, then one loves you') [10]. Projective tests can help here. 
Trying to present themselves in a favorable light, people often say not what they think, but rather how it is acceptable to talk about something in society. Often, to help in the research, respondents give answers that they think the researcher expects to hear. If the research does not aim at obtaining such answers, the results may be not quite accurate. To level out the number of such insincere, socially sanctioned responses, researchers use a combination of methods. Also, to avoid falling into the trap of fake 'right answers', sociologists use methods developed in psychology, psycholinguistics, and psychosomatics.

An important feature of projective tests in the sociological research is "an emphasis on the image (object of study) created under the influence of social factors, rather than the personal variable that aims at the projective stimulus" [8]. Unlike the use of psychological projective techniques in market and social research, incentives are transformed to address specific tasks, which are, in most cases, to identify attitudes to a particular object of study rather than to identify personal characteristics of respondents [4].

Distrust to the authorities except for the President. The direct question about trust to Vladimir Putin was answered positively by $71,5 \%$ of respondents $(24,2 \%$ do not trust) on March 13, 2020, in the WCIOM poll, and these results have been stable for a long time. However, in general, the state and the authorities do not have the people's trust. In the Russian culture, there is a proverb "One law for the rich, and another one for the poor". "It is a pity that we have lost the vision of how the country will develop and what awaits people shortly, and the assurances and declarations of the country's authorities are unfortunately not convincing enough. People hope that the authorities will fulfill at least part of their promises, but experience tells them that this is most likely not going to happen. Therefore, the distrust to the institutions of power is very high" [7]. There is also a trend of the critical perception of laws in Russia, which do not take into account social details.

Multiculturalism. The Russian Federation is a multinational state. Traditional societies in the Caucasus (priority of family, clan, traditions) differ from the more European-oriented metropolises. The classic concepts of Gemeinschaft and Gesellschaft are well illustrated here.

In 2018, there were no cases of child abuse in 10 regions. Four of them are in the North-Caucasus Federal District: Dagestan, Ingushetia, Kabardino-Balkaria, and Karachay-Cherkessia. Most of them have no statistics on child abuse from year to year [15]. It would be incorrect to judge the situation in each particular region by absolute numbers - in some regions specialists are trained to detect abuse (so there are many cases), while in other regions there are no cases and they may be required not to specify the reason. Experts generally refer to the statistics on the Caucasus as a 'weak spot'. The roots of this phenomenon can be found in the traditional communities of the Caucasian regions - their informal rules are often set higher than the law. Raising children is an area where external influences will never be allowed in the Caucasus. There is still a mentality that can be described as 'my child - my rules'. 
Non-acceptance of European values and principles of juvenile justice. The Russian society and its value structure are transforming but remain within the framework of tradition, as can be seen from the attitude to the LGBT people. According to a study conducted at the RUDN University in 2018, the attitude to homosexuality varies significantly depending on cultural values. The most tolerant regions are countries where personal freedom and the so-called 'liberal values' are highly appreciated. The CIS countries, Russia, and the countries of the Middle East, where they mostly profess Islam, keep a conservative attitude. This fact is well illustrated by the notion of the Overton window (the window of discourse), which specifies the framework for the range of opinions acceptable in public. In Europe and Latin America, the discourse on homosexuality is perceived as normal. In the CIS countries, Russia, the Middle East, and several other countries, the discourse on homosexuality is no more inconceivable, and the idea of the same-sex relationship is still perceived as radical.

Monitoring is a specific tool for the study of domestic violence, which allows to identify formal compliance of activities with the Convention. In 2020, the monitoring studied how the provisions of the Convention were implemented in 83 of 85 subjects of the Russian Federation. The monitoring consisted of three parts one statistical and two expert ones. The first statistical part is represented by the following indicators: the number of abortions and childbirths of minors; the number of mediation services; the number of rehabilitation procedures for minors; the number of minors in correctional colonies and other correctional facilities; the availability of a 'child helpline'; training and professional development of people working with children under programs which aim to prevent and protect children from sexual exploitation and abuse; information on organizations that adopted new programs and technologies for the protection of child victims of sexual violence; the number of specialists trained under the program for the protection of child victims of sexual violence, who provide assistance to families and child victims; the number of families with a child who was sexually abused; information on programs that provide assistance to families and child victims; information on families with a child who was sexually abused and received comprehensive assistance; the number of social service organizations for families and children; the number of organizations providing psychological, pedagogical, medical and social assistance; the number of multifunctional centers providing assistance to families and child victims of sexual violence; the number of specialists (full-time psychologists) accompanying minors in conflict with the law at all stages of investigation and court proceedings; the number of 'green' rooms for investigating crimes involving minors.

The expert parts of the monitoring covered the subjects' experience in implementing the Convention provisions. The monitoring included expert visits to the subjects in order to take into account the specifics of each region and its methods. In general, such a tool is a basic one and should be supplemented by other elements of the concept (surveys, projective tests, etc.). 
Let us present some results of the monitoring.

Information about the families in which a child who was sexually abused is raised. The average regional number of families in which a child is sexually abused is 70, excluding the subjects with zero indicators and lack of information (then 99). The top five subjects of the Russian Federation by the number of such families are the Perm Region (755), Kemerovo Region (544), Republic of Bashkortostan (435), Saint Petersburg (330), and the Vladimir Region (142). The average number of families in which a child was sexually abused and the family received comprehensive assistance is 37 , except for the subjects with zero indicators and lack of information (50). The five leaders are the Perm Region (755), Kemerovo Region (544), Tyumen Region (128), Stavropol Region (105), and the Altai Region (83).

The number of abortions and childbirths by minors. The average number of such abortions in Russia is 46, excluding regions with zero indicators and lack of information (48). The top five regions with the highest abortion rates are the Sverdlovsk Region (251), Saint Petersburg (189), the Rostov Region (170), Perm Region (166), and the Irkutsk Region (142). The average number of childbirths by minors is 85, excluding regions with zero indicators and lack of information (92). The top five regions with the highest absolute childbirth rates are the Stavropol Territory (389), Irkutsk Region (355), Republic of Bashkortostan (352), Sverdlovsk Region (345), and the Krasnodar Region (292).

If the ratio of minors' childbirths to abortions is more than 1 , then the more the number of childbirths by minors exceeds the number of abortions: the Stavropol Region is a leader with 10.5, then comes the Republic of Bashkortostan (7), Republic of Altai (6.6), and the Ryazan Region (6.1). Concerning the opposite trend, there are significantly fewer regions on which the number of abortions exceed the number of childbirths.

The number of minors in educational colonies. The average regional number of minors in educational colonies in 2019 is 32 people, excluding regions with zero indicators and lack of information (67). The top five regions are the Sverdlovsk Region (288), Republic of Udmurtia (165), Tyumen Region (124), Tomsk Region (107), and the Moscow Region (97). These are mainly boys, and according to absolute indicators the leader in the Republic of Udmurtia (165), while in the number of girls the leader is the Tomsk Region (107). The average number of minors in other institutions of the penal system in 2019 was 92, excluding regions with zero indicators and lack of information (119). The top five regions here are the Sverdlovsk Region (902), Altai Region (493), Khabarovsk Region (328), Amur Region (273), and the Nizhny-Novgorod Region (272). The leading regions in gender terms - keeping boys and girls in such institutions - are the Sverdlovsk Region (844 boys and 902 girls) and the Khabarovsk Regions (328 girls).

The children's helpline. $85.5 \%$ of the subjects of the Russian Federation have a children's helpline: in the education system - 57.9\%, in the social protection system $-78.4 \%$, in non-profit organizations or charity foundations $-14.4 \%$.

The number of mediation services. The average number of mediation services is 314, excluding regions with zero indicators and lack of information (322). The 
top five regions with the largest number of mediation services are the Moscow Region (1392), Rostov Region (1028), Krasnodar Region (1003), Republic of Dagestan (878), and the Orenburg Region (823). Most of such services are located in educational institutions. The average number of mediation services in educational institutions is 303 , excluding regions with zero indicators and lack of information (312).

The average number of territorial mediation services created by other government bodies and organizations is 26 , excluding regions with zero indicators and lack of information (34). The top five regions with the largest number of mediation services created by other government bodies are the Saratov Region (741), Leningrad Region (206), Kursk Region (189), Republic of Tyva (131), and the Belgorod Region (69). The top five regions with the largest absolute number of mediation services in educational organizations coincide with the general ranking, and there are several subjects with the corresponding indicator of $100 \%$, i.e., absolutely all available mediation services are provided by educational organizations (the Republic of Tyva, the Leningrad Region, and Saint Petersburg).

The number of social service organizations for families and children. The average number of social service organizations for families and children is 22, excluding regions with zero indicators and lack of information (24). The top five subjects with the largest number of such organizations are the Sverdlovsk Region (79), Krasnoyarsk Region (75), Krasnodar Region (74), Republic of Tatarstan (73), and the Volgograd Region (59).

The number of professionals working under programs aimed at preventing and protecting children from sexual exploitation and abuse. The average regional number of such specialists is 928, excluding regions with zero indicators and lack of information (1345). The leaders are the Republic of Udmurtia (27454), Altai Region (21251), Saratov Region (1099), Volgograd Region (614), and the Kaluga Region (543).

The average number of specialists with special training for programs aimed at preventing and protecting children from sexual exploitation and abuse is 31 , excluding regions with zero indicators and lack of information (62). The leaders are the Altai Region (544), Oryol Region (351), Kursk Region (271), Republic of Ingushetia (106), and the Republic of Bashkortostan (70). The average share of specialists who have special training, based on the data from regions that provided it and the data were greater than zero, is $25.4 \%$. The average number of the corresponding organizations is 4 , excluding regions with zero indicators and lack of information (9). The leading regions are the Nizhny-Novgorod Region (51), Omsk Region (34), Altai Region (27), Kirov Region (24), and the Volgograd Region (11).

The number of organizations providing psychological-pedagogical and medical-social assistance. The average number of such organizations is 65, excluding regions with zero indicators and lack of information (73). The top five subjects are the Republic of Udmurtia (1526), Omsk Region (808), Tomsk Region (491), Khabarovsk Region (369), and the Vologda Region (309). 
The number of specialized multifunctional centers helping families and child victims of sexual violence. The average number of such centers is 4 , excluding regions with zero indicators and lack of information (10). The top five subjects with the largest number of such organizations are the Sverdlovsk Region (230), Moscow (11), Amur Region (10), Kaliningrad Region (8), and the Kirov Region (6).

The number of specialized 'green' rooms for investigating crimes related to minors. The average number of such 'green' rooms is just 1 , excluding regions with zero indicators and lack of information (3). The top five subjects here are the Tyumen Region (26), Republic of Crimea (19), Perm Region (12), Chelyabinsk Region (7), and the Kemerovo Region (4).

The number of specialists accompanying minors who have come into conflict with the law at all stages of the investigation and court proceedings. The average number of such specialists is 80 , excluding regions with zero indicators and lack of information (115). The top five subjects are the Omsk Region (537), Republic of Komi (497), Altai Region (470), Penza Region (424), and the Kaluga Region (418).

The number of professionals trained under the Child Sexual Violence Protection Program and assisting families and child victims of violence. The average number of the specialists trained to protect child victims of sexual abuse and to assist families and child victims of violence is 32 , excluding regions with zero indicators and lack of information (44). The top five subjects are the Tyumen Region (366), Trans-Baikal Region (190), Republic of Tatarstan (100), Omsk Region (77), and the Voronezh Region (74).

Thus, the Lanzarote Convention is an excellent example of the implementation of a socially important idea, but it will be effective only if the social-cultural features of countries are taken into account. The reason is that legislation cannot be rigid - it should be adapted to the specific society. Besides, global developments are changing the world and making adjustments to social reality, which should also be taken into account when analyzing the implementation of the Convention. Thus, reportedly, many domestic violence victims were trapped in their homes with a violent perpetrator during the coronavirus pandemic [13].

The concept of the study of violence against children should take into account the social and social-cultural aspects and can be based on the traditional model of monitoring to assess the implementation of the Convention. Additional expert interviews, opinion polls and surveys based on projective techniques can help to reveal the social-cultural specifics of every region or country under study.

\section{Funding}

The article was prepared within the state assignment No. 075-00167-20-03 "Social-humanitarian foundations for countering extremism".

\section{References}

[1] Callaghan J.E.M., Alexander J.H. Understanding Agency and Resistance Strategies (UNARS): Children's Experiences of Domestic Violence. Northampton; 2015.

[2] Dyachenko L.I., Filipov A.I., Dyachenko K.V. Peculiarities of mentality and its impact on the intercultural communication (on the example of Russia and the USA). SanktPeterburgsky Obrazovatelny Vestnik. 2018; 11-12. (In Russ.). 
[3] Gamila Muhammad Nasser Ahmed. Psychological consequences of sexual and physical violence in Yemeni children aged 6-11 years. Russian Psychological Journal. 2010; 1.

[4] Gureev S.V. Use of projective tests in sociological research: Peculiarities of using graphical data (respondents' drawings) in the method of group discussions. 2015. URL: http://www.sociologos.ru/upload/File/Gureev.pdf.

[5] Kleinsorge T. Legal protection of children from sexual exploitation: The "Lanzarote Convention" and the One in Five campaign. 2011. URL: https://docplayer.net/4492929Legal-protection-of-children-from-sexual-exploitation-the-lanzarote-convention-and-theone-in-five-campaign.html.

[6] Kozlov N.I. Russian mentality. Psychologos. 2013. URL: https://www.psychologos.pro/ articles/view/77194-russian-mentality.

[7] Lev Gudkov: "Mistrust in the institutions of power is very high". Novaya Gazeta. September 6, 2018. (In Russ.).

[8] Melnikova O.T. Focus-Groups in Marketing Research: Methodology and Techniques of Qualitative Research in Social Psychology]. Moscow; 2013. (In Russ.).

[9] Oganesjan C.A. Juvenile victimology. Jurisprudence: Problems and Prospects: Proceedings of the VIII International Scientific Conference. Kazan; 2019. (In Russ.).

[10] Popova I.V. A study of the domestic violence. Nauchny Dialog. 2012; 4. (In Russ.).

[11] Rankings of trust to politicians, assessments of the president's work, support for political parties. March 13, 2020. URL: https://wciom.ru/index.php?id=236\&uid=10198. (In Russ.).

[12] Shikula I.R. On the problem of victimological prevention of sexual crimes against minors. Juvenile Justice Issues. 2013; 27.

[13] Gulati Sh., Sarai S.K., Lippmann S. Covid-19 and domestic violence. 2020. URL: https://www.researchgate.net/publication/344905679_COVID-19_and_domestic_violence.

[14] The Lanzarote Convention. URL: https://www.coe.int/en/web/children/lanzarote-convention.

[15] The authorities opened data on child abuse in the regions: There were no such cases in four regions of the North Caucasus. August 14, 2019. URL: https://www.rbc.ru/society/14/08/ 2019/5d5126249a79479ea5f4db0a. (In Russ.).

[16] Zyrjanova J.V. Victimogenic factors of domestic sexual violence against minors (on the example of the Republic of Khakassia). Prologue: Journal of Law. 2013; 3. (In Russ.).

DOI: 10.22363/2313-2272-2021-21-2-311-321

\section{Проблема детского насилия: социальные и социокультурные аспекты*}

\section{Ж.В. Пузанова, В.М. Филиппов, М.А. Симонова, Т.И. Ларина}

Российский университет дружбы народов ул. Миклухо-Маклая, 6, Москва, 117198, Россия (e-mail:simonova-ma@rudn.ru; filippov-vm@rudn.ru; puzanova-zhv@rudn.ru; larina-ti@rudn.ru)

Аннотация. Ратификация Лансаротской конвенции Россией в 2013 году влечет за собой ряд вопросов о ее реализации, которые не могут быть решены без привлечения социальногуманитарных наук. В статье использованы принципы социологии, психологии и юриспруденции, на основании которых представлена концепция эмпирического изучения семейного

\footnotetext{
* ( П Пузанова Ж.В., Филиппов В.М., Симонова М.А., Ларина Т.И., 2021

Статья поступила 27.01.2021 г. Статья принята к публикации 02.04.2021 г.
} 
насилия в отношении детей - для повышения эффективности реализации Лансаротской конвенции в российской действительности. Концепция включает в себя два блока проблемы социальные и социокультурные аспекты. Авторы приводят статистические данные о количестве семей, в которых воспитывается ребенок, подвергшийся сексуальному насилию, количестве абортов и родов среди несовершеннолетних, количестве несовершеннолетних, которые содержались в воспитательных колониях, функционировании детского телефона доверия, количестве служб медиации, количестве организаций социального обслуживания семьи и детей, численности специалистов, работающих с детьми по программам, направленным на предупреждение и защиту детей от сексуальной эксплуатации и злоупотреблений, количестве организаций, оказывающих психолого-педагогическую медико-социальную помощь, количестве специализированных многопрофильных центров, оказывающих помощь семьям и детям-жертвам сексуального насилия, количестве специализированных «зеленых» комнат для расследования преступлений, связанных с несовершеннолетними, количестве специалистов (штатных психологов), сопровождающих несовершеннолетних, вступивших в конфликт с законом на всех этапах расследования и судебного производства, количестве специалистов, прошедших обучение по программе защиты детей-жертв сексуального насилия и оказывающих помощь семьям и детям-жертвам насилия. Статья будет полезна специалистам, занимающимся проблемами реализации положений Лансаротской конвенции, а также изучением факторов семейного насилия в отношении детей.

Ключевые слова: насилие; дети; сексуальное насилие; виктимология; общественное мнение; Лансаротская конвенция; мониторинг

\section{Информация о финансировании}

Статья подготовлена в рамках государственного задания №075-00167-20-03 «Социогуманитарные основы противодействия экстремизму». 